\title{
Human Umbilical Cord Blood Serum Has Higher Potential in Inducing Proliferation of Fibroblast than Fetal Bovine Serum
}

\author{
Ferry Sandra ${ }^{1,2}$, Rita Lahirin ${ }^{3}$ \\ ${ }^{1}$ Department of Biochemistry and Molecular Biology, Division of Oral Biology, Faculty of Dentistry, Trisakti University, Jakarta, \\ Indonesia \\ ${ }^{2}$ Doctoral Program in Medical Science, Faculty of Medicine, University of Sumatera Utara, Medan, Indonesia \\ ${ }^{3}$ Postgraduate Program in Anti Aging, Faculty of Medicine, Udayana University, Denpasar, Indonesia
}

Background: Cytokines and growth factors were reported to play an important role in stimulating fibroblast proliferation. In vitro culture, fibroblast is mostly culture in medium containing fetal bovine serum (FBS). Human umbilical cord blood (hUCB) has been reported to have low immunogenic property and potential in wound healing, so therefore hUCB serum (hUCBS) could be potential and were investigated in current study.

Materials and Methods: Five hUCBs were collected from healthy volunteers with normal delivering procedure. hUCB was ex utero immediately collected from umbilical vein in vacutainers and processed. NIH3T3 cells were cultured in DMEM with $10 \%$ FBS or $5-20 \%$ hUCBS for 48 hours. Cells were then quantified using MTT assay. Protein concentration of FBS and hUCBS were quantified using Bradford assay.

Results: NIH3T3 cells density grown in DMEM with 10\% FBS was the lowest. NIH3T3 cells densities were increased along with the increment of hUCBS concentrations. MTT results showed that average number of NIH3T3 cells grown in DMEM with $10 \%$ FBS was $6,185 \pm 1,243$. Meanwhile average numbers of NIH3T3 cells grown in DMEM with $5 \%, 10 \%$ and $20 \%$ hUCBS were $8,126 \pm 628,9,685 \pm 313$ and $12,200 \pm 304$, respectively. Average numbers of NIH3T3 cells grown in DMEM with $5 \%$ hUCBS were significantly higher than the ones with $10 \%$ FBS $(p=0.000)$. Bradford results showed that concentration of hUCBS was significantly higher than the one of FBS $(p=0.000)$.

Conclusion: hUCBS could induce higher proliferation rate of NIH3T3 cells than FBS. Hence hUCBS could be suggested as an alternate of FBS in inducing fibroblast.

Keywords: NIH3T3, fibroblast, UCB, serum, FBS, proliferation

\section{Introduction}

Fibroblasts are the cell type that can synthesize extracellular matrix and collagen, which plays an important role in wound healing. ${ }^{1,2}$ Fibroblasts are cells were most abundant in connective tissue. ${ }^{1,2}$ Fibroblasts make collagen, glycosaminoglycan, reticular, elastin fibers and glycoproteins that are part of the extracellular matrix so that the increase of fibroblasts affect skin elasticity, muscle tone, bone strength and others where it is extremely 
important in preventing premature aging. ${ }^{1}$ Cytokines and growth factors were reported to play an important role in stimulating fibroblast proliferation. ${ }^{3,4}$ Meanwhile in in vitro culture, fibroblast is mostly culture in medium containing fetal bovine serum (FBS), which has plenty of cytokines and growth factors. Nevertheless, in searching for better supplement, FBS has been compared to various products, including human platelet lysate and serum. ${ }^{5}$

It has been confirmed that stem cell can induce and activate fibroblast to participate in wound healing by producing and expressing TGF- $\beta$ and other cytokines. ${ }^{6}$ Therefore, stem cell were reported to be effective to promote re-epithelialization in burns. ${ }^{7}$ Adult stem cells, which could be isolated from bone marrow ${ }^{8-10}$, umbilical cord blood ${ }^{10-12}$, adipose tissue $e^{9,13}$, peripheral blood ${ }^{10,14,15}$, skin and hair follicles, are being explored extensively to facilitate the healing of both acute and chronic wounds. ${ }^{7,16}$

Human umbilical cord blood (hUCB) has been reported to have low immunogenic property. ${ }^{16,17}$ Therefore hUCB could be suggested as an alternative source of stem cells for allogeneic transplantation. ${ }^{16,17}$ Beside in wound healing, secretome of hUCB stem cell was shown to induce apoptosis and inhibit growth of cancer cells. ${ }^{18}$ Since hUCB was shown as a potential source, hUCB serum (hUCBS) were investigated in current study.

\section{Materials and methods}

\section{hUCB collection and hUCBS production}

Five hUCBs were collected from healthy volunteers underwent normal delivery procedure at Mohammad Ridwan Meuraksa Military Hospital in Jakarta. Briefly, after volunteer mother signed informed consent and delivered baby, $50 \mathrm{~mL}$ hUCB was collected immediately ex utero from umbilical vein in $510 \mathrm{~mL}$-vacutainers (Becton Dickinson, Franklin Lakes, NJ, USA). Vacutainers were seated for 10 minutes and centrifuged. After complete separation resulted, hUCBS was collected and stored in a $-20^{\circ} \mathrm{C}$ fridge. The study protocol was approved by The Ethical Committee of Faculty of Medicine Udayana University/Sanglah Central General Hospital (No. 570/Skrt/VIII/2010) and permitted by The Medical Committee of Mohammad Ridwan Meuraksa Military Hospital (No. SK/53-6/iV/2010).

\section{NIH3T3 cell culture}

NIH3T3 cells were cultured in Dulbecco's Modified Eagle Medium (DMEM) (Gibco, Grand Island, NY, USA) containing 10\% FBS (Gibco), penicillin, streptomycin and amphotericin B (Sigma-Aldrich, St. Louis, MO, USA) in a humidified, $37^{\circ} \mathrm{C}, 5 \% \mathrm{CO} 2$ incubator. Upon reaching $80 \%$ confluency, cells were detached with trypsin (Gibco), split and propagated.

\section{3-(4,5-dimethylthiazol-2-yl)-2,5-Diphenyltetrazolium bromide (MTT) assay}

The MTT assay provides a quantitative measurement of viable cells by determining the amount of formazan crystals produced by metabolically active cells. ${ }^{19,20}$ Briefly, $5 \times 10^{3}$ cells were seeded into each well of 96-well plate in medium containing FBS, hUCBS or medium merely. Cells were incubated for 48 hours. Ten $\mu 1$ of $5 \mathrm{mg} / \mathrm{mL}$ MTT (SigmaAldrich) in phosphate buffer saline (PBS) was added to each well. The plate was then incubated for 4 hours, and then the medium was discarded and formazan crystals were dissolved in $100 \mu \mathrm{l}$ of $0.1 \mathrm{~N} \mathrm{HCl}$. The absorbance was measured at $570 \mathrm{~nm}$ by a microplate reader (Bio-Rad, Richmond, CA, USA). Untreated cells were counted with a hemacytometer and used for interpolating the absorbance.

\section{Bradford assay}

Bradford assay is a protein determination method that involves the binding of Coomassie Brilliant Blue G-250 dye to proteins. For this research, Quick Start ${ }^{\mathrm{TM}}$ Bradford Protein Assay (Bio-Rad) was applied. All procedures were conducted according to instruction manual. Briefly, bovine serum albumin (BSA) as the standard, FBS and hUCBS were serial diluted in a 96-well plate. Then, $1 \mathrm{x}$ dye reagent was added to each well and seated for 15 minutes at room temperature. The absorbance was measured at $595 \mathrm{~nm}$ by a microplate reader.

\section{Statistical analysis}

Statistical analyses were performed using IBM SPSS Statistics for Macintosh version 21 (SPSS IBM, Armonk, NY, USA). Mann-Whitney test was used to compare two population means. Statistically significance is expressed as $p<0.05$.

\section{Results}

hUCBS induced higher proliferation rate of NIH3T3 cells than FBS

In Figure 1, NIH3T3 cells densities grown in DMEM with $10 \% \mathrm{FBS}$ and various concentration of hUCBS could be 
A

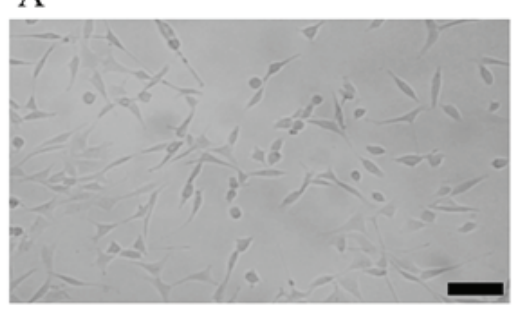

C

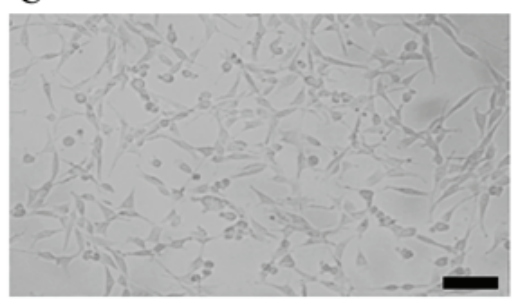

B

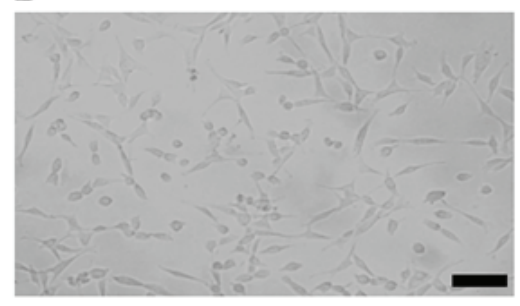

D

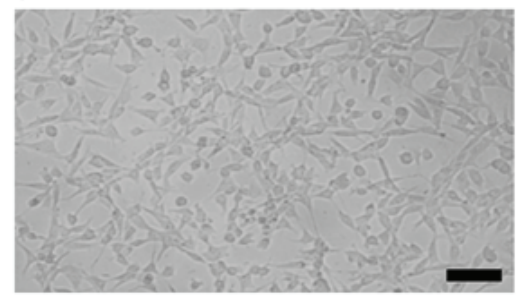

Figure 1. Growth of NIH3T3 cells in medium containing FBS or hUCBS. Five thousand $\mathrm{NiH} 3 \mathrm{~T} 3$ cells were seeded and cultured in 96well plate with medium containing $10 \%$ FBS, $5 \%$ hUCBS, $10 \%$ hUCBS or $20 \%$ hUCBS for 48 hours. Cells were then documented using an inverted light microscope. Detailed procedures are described in "Materials and Methods". Each picture shows the typical result of 3 independent results. Black bar: $100 \mu \mathrm{m}$. observed. NIH3T3 cells density grown in DMEM with $10 \%$ FBS was the lowest (Figure 1A). NIH3T3 cells densities were increased along with the increment of hUCBS concentrations (Figure 1B-D).

MTT results confirmed the densities results (Figure 2). Average number of NIH3T3 cells grown in DMEM with $10 \%$ FBS was $6,185 \pm 1,243$. Meanwhile average numbers of NIH3T3 cells grown in DMEM with 5\%, 10\% and 20\% hUCBS were $8,126 \pm 628,9,685 \pm 313$ and $12,200 \pm 304$, respectively. Average numbers of NIH3T3 cells grown in DMEM with $5 \%$ hUCBS were significantly higher than the ones with $10 \%$ FBS $(p=0.000)$. Numbers of NIH3T3 cells grown in DMEM with 10\% hUCBS were significantly

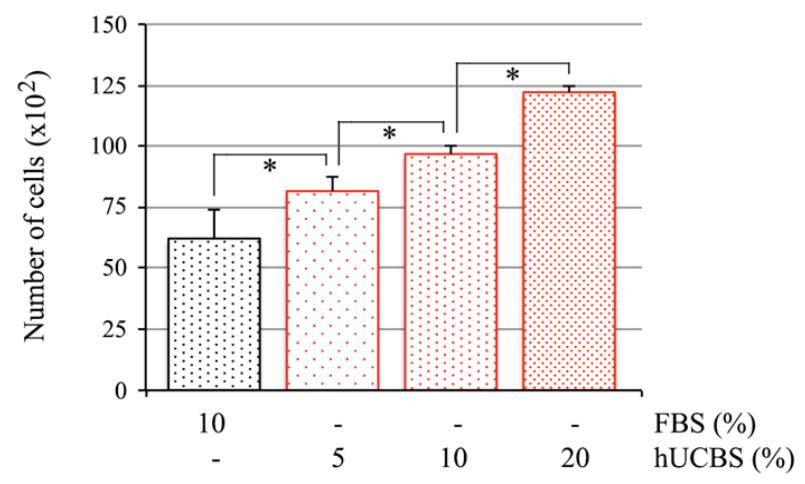

Figure 2. hUCBS induced proliferation of NIH3T3 cells. Five thousand NiH3T3 cells were seeded and cultured in 96well plate with medium containing $10 \%$ FBS, 5\% hUCBS, $10 \%$ hUCBS or $20 \%$ hUCBS for 48 hours. Cells were then subjected to NIH3T3 assay. Detailed procedures are described in "Materials and Methods". This experiment was performed in triplicate and repeated three times. *Mann Whitney test, $p<0.05$. higher than the ones with $5 \%$ hUCBS $(p=0.000)$. Numbers of NIH3T3 cells grown in DMEM with $20 \%$ hUCBS were significantly higher than the ones with $10 \%$ hUCBS $(p=0.000)$.

\section{Protein concentration of hUCBS was higher than FBS}

As shown in Figure 3, protein concentration of FBS was $3.23 \pm 0.54 \mathrm{~g} / \mathrm{dL}$, while protein concentration of hUCBS was $5.04 \pm 0.41 \mathrm{~g} / \mathrm{dL}$. The concentration of hUCBS was significantly higher than the one of FBS $(p=0.000)$.

\section{Discussion}

Our current results showed that hUCBS induced proliferation of NIH3T3 cells in a concentration dependent manner. Although protein concentration of hUCBS was almost twice higher than the one of FBS, 5\% hUCBS resulted significant higher average number of NIH3T3 cells than 10\% FBS did. These results showed that the cell numbers resulted were not in a protein concentration dependent manner. hUCBS and FBS should have different protein components and hUCBS contained more potential components in inducing proliferation of NIH3T3 cells.

hUCBS has been reported superior in inducing proliferation of mesenchymal stem cell (MSC), ${ }^{21-24}$ human bone marrow-derived progenitor cells, ${ }^{25}$ human derived Panc-1 cell lines ${ }^{26}$ and human foreskin fibroblasts ${ }^{27}$ than FBS or fetal calf serum (FCS). Not only for cell growth, human pluripotent stem cell lines could maintain their pluripotencies, differentiation capacities, and karyotypic stabilities after being co-cultured for extended period with 


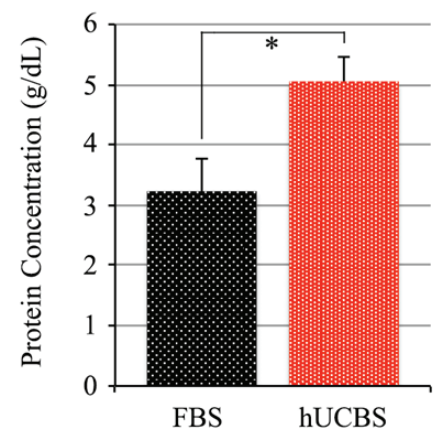

Figure 3. Amount of protein in FBS or hUCBS. FBS and hUCBS used in this research were serial diluted and quantified with Bradford assay. Detailed procedures are described in "Materials and Methods". This experiment was performed in triplicate. *Mann Whitney test, $p<0.05$.

hUCBS. ${ }^{24,27}$ In addition, hUCBS cryopreservation has been performed extensively with modified methods. ${ }^{24,28}$ Nevertheless, hUCBS is also useful when cells were induced for differentiation. ${ }^{22,25,26}$ Regulatory effects of hUCBS on MSC included selective activation of epidermal growth factor (EGF) and platelet-derived growth factor (PDGF) signals in MSC. ${ }^{22}$

Proliferation of NIH3T3 cells could be regulated by several growth factors. EGF increased NIH3T3 cell proliferation along with the increment of EGF concentration until $25 \mathrm{ng} / \mathrm{mL}$, which was the optimal EGF concentration to induce the maximum NIH3T3 cell proliferation. ${ }^{29}$ EGF induced the NIH3T3 cell proliferation through MitogenActivated Protein Kinase (MAPK) / Extracellular signalRegulated Kinase (ERK) signaling pathway, ${ }^{30}$ which is a major signaling pathway involving cellular proliferation though Rat sarcoma (Ras) / Rapidly accelerated fibrosarcoma (Raf) / ERK cascade. ${ }^{31}$ Another growth factor, PDGF, that was also contained in hUCBS, ${ }^{32}$ were reported to induce phosphatidylinositol 3-kinase (PI3K) / $\mathrm{Akt}^{32,33}$ and Ras/ ERK signaling pathways as well. ${ }^{32-34}$

In conclusion, our current results suggested that hUCBS might play an important role in proliferation of NIH3T3 cells, since hUCBS could induce higher proliferation rate of NIH3T3 cells than FBS. Hence hUCBS could be suggested as an alternate of FBS in inducing fibroblast. However, further research should be explored to test hUCBS for other fibroblast cell lines.

\section{References}

1. Tracy LE, Minasian RA, Caterson EJ. Extracellular Matrix and Dermal Fibroblast Function in the Healing Wound. Adv Wound
Care (New Rochelle). 2016; 5(3): 119-36.

2. Bainbridge P. Wound healing and the role of fibroblasts. J Wound Care. 2013; 22(8): 407-8, 410-12.

3. Borg M, Brincat S, Camilleri G, Schembri-Wismayer P, Brincat M, Calleja-Agius J. The role of cytokines in skin aging. Climacteric. 2013; 16(5): 514-21.

4. Żerańska J, Pasikowska M, Szczepanik B, Mlosek K, Malinowska $\mathrm{S}$, Dębowska RM, et al. A study of the activity and effectiveness of recombinant fibroblast growth factor (Q40P/S47//H93G rFGF-1) in anti-aging treatment. Postepy Dermatol Alergol. 2016; 33(1): 2836.

5. Suri K, Gong HK, Yuan C, Kaufman SC. Human Platelet Lysate as a Replacement for Fetal Bovine Serum in Limbal Stem Cell Therapy. Curr Eye Res. 2016; 41(10): 1266-73.

6. Zhong J, Hu N, Xiong X, Lei Q, Li L. A novel promising therapy for skin aging: dermal multipotent stem cells against photoaged skin by activation of TGF- $\beta /$ Smad and p38 MAPK signaling pathway. Med Hypotheses. 2011; 76(3): 343-6.

7. Moenadjat Y, Merlina M, Surjadi CF, Sardjono CT, Kusnadi Y, Sandra F. The application of human umbilical cord blood mononuclear cells in the management of deep partial thickness burn. Med J Indones. 2013; 22(2): 92-9.

8. Sandra F, Sidiq KM, Halim D. Terapi Stem Cell - Terobosan Kedokteran Modern untuk Penderita Gagal Jantung. Jakarta: Grasindo; 2012

9. Lubis AM, Sandhow L, Lubis VK, Noor A, Gumay F, Merlina M, et al. Isolation and cultivation of mesenchymal stem cells from iliac crest bone marrow for further cartilage defect management. Acta Med Indones. 2011; 43(3): 178-84.

10. Tendean M, Oktaviono YH, Sandra F. Cardiomyocyte Reprogramming: A Potential Strategy for Cardiac Regeneration. Mol Cell Biomed Sci. 2017; 1(1): 1-5.

11. Aini N, Wanandi SI, Sandra F. Expression of Transcription Factor Oct-4 as Pluripotency Marker of Fetomaternal Tissues Umbilical Cord Blood, Cord Blood Matrix and Placenta. Maj Kedokt Indon. 2009; 59(4): 152-7.

12. Wijaya MT, Sandra F. Proses dalam Umbilical Cord Blood Banking. CDK. 2007; 34(157): 217-20.

13. Sardjono CT, Setiawan M, Frisca, Saputra V, Aniko G, Sandra F. Application of a modified method for stem cell isolation from lipoaspirates in a basic lab. Med J Indones. 2009; 18(2): 91-6.

14. Sandra F, Oktaviono YH, Widodo MA, Dirgantara Y, Chouw A, Sargowo D. Endothelial progenitor cells proliferated via MEKdependent p42 MAPK signaling pathway. Mol Cell Biochem. 2015; 400(1-2): 201-6.

15. Nababan SHH, Purba AP, Frisca, Aini N, Setiawan B, Sandra F. Peranan Endothelial Progenitor Cell dalam Neovaskularisasi. CDK. 2007; 34(158): 257-9.

16. Teng M, Huang Y, Zhang H. Application of stems cells in wound healing - an update. Wound Repair Regen. 2014; 22(2): 151-60.

17. Sardjono CT, Setiawan M, Suyatna FD, Japutri I, Setiawan B, Sandra F. Immunogenicity characterization of mononucleated cells originated from umbillical cord blood. Med J Indones. 2010; 19(1): $14-20$.

18. Sandra F, Sudiono J, Sidharta EA, Sunata EP, Sungkono DJ, Dirgantara Y, Chouw A. Conditioned media of human umbilical cord blood mesenchymal stem cell-derived secretome induced apoptosis and inhibited growth of HeLa cells. Indones Biomed J. 2014; 6(1): 57-62. 
19. Widowati $\mathrm{W}$, Mozef $\mathrm{T}$, Risdian $\mathrm{C}$, Ratnawati $\mathrm{H}$, Tjahjani $\mathrm{S}$, Sandra F. The Comparison of Antioxidative and Proliferation Inhibitor Properties of Piper betle L., Catharanthus roseus [L] G.Don, Dendrophtoe petandra L., Curcuma mangga Val. Extracts on T47D Cancer Cell Line. Int Res J Biochem Bioinform. 2011; 1(2): 22-8.

20. Arung ET, Kusuma IW, Purwatiningsih S, Roh SS, Yang CH, Jeon $\mathrm{S}$, et al. Antioxidant Activity and Cytotoxicity of the Traditional Indonesian Medicine Tahongai (Kleinhovia hospita L.) Extract. J Acupunct Meridian Stud. 2009; 2(4): 306-8.

21. Shetty P, Bharucha K, Tanavde V. Human umbilical cord blood serum can replace fetal bovine serum in the culture of mesenchymal stem cells. Cell Biol Int. 2007; 31(3): 293-8.

22. Jung J, Moon N, Ahn JY, Oh EJ, Kim M, Cho CS, et al. Mesenchymal stromal cells expanded in human allogenic cord blood serum display higher self-renewal and enhanced osteogenic potential. Stem Cells Dev. 2009; 18(4): 559-71.

23. Darmayanti S, Triana R, Chouw A, Dewi NM. Is Stem Cell a Curer or an Obstruction? Mol Cell Biomed Sci. 2017; 1(1): 17-27.

24. Halim D, Murti H, Sandra F, Boediono A, Djuwantono T, Setiawan B. Stem Cell: Dasar Teori \& Aplikasi Klinis. Jakarta: Erlangga; 2010.

25. Phadnis SM, Joglekar MV, Venkateshan V, Ghaskadbi SM, Hardikar AA, Bhonde RR. Human umbilical cord blood serum promotes growth, proliferation, as well as differentiation of human bone marrow-derived progenitor cells. In Vitro Cell Dev Biol Anim. 2006; 42(10): 283-6.

26. Challa SS, Kiran GS, Bhonde RR, Venkatesan V. Enhanced neogenic potential of Panc-1 cells supplemented with human umbilical cord blood serum--An alternative to FCS. Tissue Cell. 2011; 43(4): 26670 .
27. Rungsiwiwut $R$, Ingrungruanglert $P$, Numchaisrika $P$, Virutamasen P, Phermthai T, Pruksananonda K. Human Umbilical Cord BloodDerived Serum for Culturing the Supportive Feeder Cells of Human Pluripotent Stem Cell Lines. Stem Cells Int. 2016; 2016: 4626048. doi: $10.1155 / 2016 / 4626048$.

28. Djuwantono T, Wirakusumah FF, Achmad TH, Sandra F, Halim D, Faried A. A comparison of cryopreservation methods: Slowcooling vs. rapid-cooling based on cell viability, oxidative stress, apoptosis, and $\mathrm{CD} 34^{+}$enumeration of human umbilical cord blood mononucleated cells. BMC Res Notes. 2011; 4: 371. doi: 10.1186/1756-0500-4-371.

29. Wu Z, Tang Y, Fang H, Su Z, Xu B, Lin Y, et al. Decellularized scaffolds containing hyaluronic acid and EGF for promoting the recovery of skin wounds. J Mater Sci Mater Med. 2015; 26(1): 5322. doi: 10.1007/s10856-014-5322-1.

30. Lee MY, Jeong WJ, Oh JW, Choi KY. NM23H2 inhibits EGF- and Ras-induced proliferation of NIH3T3 cells by blocking the ERK pathway. Cancer Lett. 2009; 275(2): 221-6.

31. Roberts PJ, Der CJ. Targeting the Raf-MEK-ERK mitogen-activated protein kinase cascade for the treatment of cancer. Oncogene. 2007; 26(22): 3291-310.

32. Dong Y, Jia L, Wang X, Tan X, Xu J, Deng Z, et al. Selective inhibition of PDGFR by imatinib elicits the sustained activation of ERK and downstream receptor signaling in malignant glioma cells. Int J Oncol. 2011; 38(2): 555-69.

33. Gueller S, Hehn S, Nowak V, Gery S, Serve H, Brandts CH, et al Adaptor protein Lnk binds to PDGF receptor and inhibits PDGFdependent signaling. Exp Hematol. 2011; 39(5): 591-600.

34. Eger G, Papadopoulos N, Lennartsson J, Heldin CH. NR4A1 promotes PDGF-BB-induced cell colony formation in soft agar. PLoS One. 2014; 9(9): e109047. doi: 10.1371/journal.pone.0109047. 